\title{
Prevalence of ectoparasites and bacteriological diagnosis in Nile tilapia bred in net-tanks in the Corvo's river, Paraná, Brazil ${ }^{1}$
}

\section{Prevalência de ectoparasitos e diagnóstico bacteriológico em tilápia do Nilo criadas em tanques-rede no Rio do Corvo, Paraná, Brasil ${ }^{1}$}

\author{
Ricardo Hideo Mori ${ }^{2 *}$; Renata Alari Chedid²; Graciela Lucca Braccini³ \\ Ricardo Pereira Ribeiro ${ }^{4}$; Carlos Antonio Lopes de Oliveira ${ }^{4}$; \\ Lucienne Garcia Pretto-Giordano ${ }^{5}$; Lauro Vargas ${ }^{4}$
}

\begin{abstract}
Predominance of ectoparasites and bacteria diagnosis were identified in Nile tilapia (Oreochromis niloticus), GIFT strain, bred in net-tanks at different densities. Current experiment was performed in the Corvo's river, State of Paraná, Brazil, in two cycles: cycle A installed in August 2010 with 155 days, and cycle B, installed in February 2011 with 128 days. Twenty $6.8 \mathrm{~m}^{-3}(2.0 \times 2.0 \times 1.7 \mathrm{~m})$ net-tanks were employed, using $6.0 \mathrm{~m}^{-3}$ and five densities $\left(150,175,200,225\right.$ and $\left.250 \mathrm{fish} / \mathrm{m}^{-3}\right)$, with four replications each. No significant difference was registered with regard to the prevalence of ectoparasites due to densities in the two experimental cycles. In the months of September to November cycle A displayed increase in the predominance of Trichodina and a decrease in the prevalence of Monogenoidea and mixed parasites. Further, an inverse relationship with a decrease in the prevalence of Trichodina and an increase in the prevalence of Monogenoidea and mixed parasites occurred during October and November. Trochodina prevalence occurred in October and November. Cycle B showed a significant difference in total prevalence of ectoparasites due to months. There was an increase in tricodinid infestation between March and June in proportion to increase of density and throughout the experiment. More care should be taken with regard to densities during the period. No positive result was registered in the diagnosis of bacteria in Nile tilapias in the two cycles. The above was perhaps due to the water quality standards for the species and the cleanliness of the net-tanks for the experiments. Density increase did not affect the prevalence of ectoparasites and influenced tricodinid infestation between March and June.
\end{abstract}

Key words: Densities, monogenoidea, Oreochromis niloticus, Trichodina

\section{Resumo}

Foram identificados a prevalência de ectoparasitos e o diagnóstico de bactérias em tilápia do Nilo

\footnotetext{
${ }^{1}$ Parte da dissertação de mestrado do primeiro autor, apresentada ao Programa de Pós-Graduação em Ciência Animal da Universidade Estadual de Maringá, UEM como parte dos requisitos para a obtenção do título de Mestre em Produção Animal. Financeamento: CNPq.

2 Discentes de Pós-graduação em Aquicultura, Centro de Aqüicultura, CAUNESP, Universidade Estadual Paulista, UNESP, Jaboticabal, SP, Brasil. E-mail: moritsunami@hotmail.com; rechedid@outlook.com

${ }^{3}$ Discente de Pós-graduação em Ciências Agrícolas, Universidade Estadual de Maringá, UEM, Maringá, PR, Brasil. E-mail: gracielabh@ibest.com.br

4 Profs. do Programa de Pós-graduação em Zootecnia, UEM, Maringá, PR, Brasil. E-mail: rpribeiro@uem.br; caloliveira@uem. br; lvargas@uem.br

${ }^{5}$ Prof $^{\mathrm{a}}$, Dept ${ }^{\mathrm{O}}$ de Medicina Veterinária Preventiva, Universidade Estadual de Londrina, UEL, Londrina, PR, Brasil. E-mail: lgiordano@uel.br

* Author for correspondence
} 
(Oreochromis niloticus) da variedade GIFT, criadas em tanques-rede, utilizando diferentes densidades. $\mathrm{O}$ experimento foi conduzido no Rio do Corvo, PR, em dois ciclos: ciclo A, implantado em agosto de 2010 com duração de 155 dias e ciclo B, implantado em fevereiro de 2011 com duração de 128 dias. Para cada ciclo foram instalados 20 tanques-rede de $6,8 \mathrm{~m}^{-3}(2,0 \times 2,0 \times 1,7 \mathrm{~m})$, com $6,0 \mathrm{~m}^{-3}$ úteis, adotando cinco densidades $\left(150,175,200,225\right.$ e 250 peixes $\left./ \mathrm{m}^{-3}\right)$, com quatro repetições. Não houve diferença significativa na prevalência de ectoparasitos em relação às densidades nos dois ciclos de experimento. Observou-se no nos meses de setembro a novembro do ciclo A um aumento na prevalência de Trichodina e decréscimo na prevalência de Monogenoidea e parasitismo misto, nos meses de outubro e novembro observou-se uma relação inversa com uma diminuição na prevalência de Trichodina e aumento na prevalência de Monogenoidea e parasitismo misto. Os meses de outubro e novembro apresentaram a maior prevalência de Trichodina do ciclo A. No ciclo B ocorreu uma diferença significativa na prevalência total de ectoparasitos em relação aos meses. Em relação à categoria de infestação por tricodinídeos, nos meses de março a junho houve um aumento na medida em que aumentava-se a densidade e no decorrer do experimento, justificando tomar mais cuidado com densidades elevadas neste período. Não se observou nenhum resultado positivo no diagnóstico de bactérias nas tilápias do Nilo, nos dois ciclos, possivelmente devido a limpeza dos tanques-rede na implantação dos experimentos e manejo adequado adotado no experimento. Concluiu-se que o aumento da densidade não influenciou na prevalência de ectoparasitos, tendo influência para categoria de infestação por tricodinídeos de março a junho.

Palavras-chave: Densidades, monogenoidea, Oreochromis niloticus, Trichodina

\section{Introduction}

Fish breeding in net-tanks consists of an intensive breeding system, introduced in the 1980s, and makes use of the environment with great productivity within a sustainable method. It is characterized by high stocking in which fish are maintained in a limited volume with free and constant water circulation. Fish are maintained in the tanks and receive controlled feed for the increase of biomass till they are due for the market. Diseases occurring in the system may put their health in danger and bring economical liabilities to the entrepreneurs (BONDAD-REANTASO et al., 2005; AKOLL et al., 2012).

The Nile tilapia (Oreochromis niloticus) is a species which is most commonly used in net-tanks, owing to such positive traits as genetic plasticity, rusticity, early development, short generation, facility for adaptation to adverse conditions, high quality flesh, resistance to stress and various types of pollutants (EL-SAYED, 2006; BRACCINI et al., 2013). The tilapia has good feed conversion coupled to reproduction facility in confinement. Furthermore, natural (phytoplankton) and commercial feed with low protein rates and low production costs may be employed.

Since intensive production in net-tank systems is highly liable to variations in water quality and infection agents (KUBITZA; KUBITZA, 2004), monitoring and correct positioning of net-tanks in the water are required so that the fish's normal physiological responses could be stimulated. The above is also needed to avoid nutrition, infection and parasite diseases coupled to evaluations of the environmental impacts that the activity may cause (MENEZES; BEYRUTH, 2003).

Parasitic diseases are among the most frequent problems in aquaculture. Ectoparasites serve as a "gateway" for bacterial and fungal agents, compromising animal performance and disseminate pathogens into the environment, causing losses to producers and public health risks (LIMA; LEITE, 2006).

Tricodinids and monogenoidea are among the most important ectoparasites in the Nile tilapia (MARTINS et al., 2006; VALLADÃO et al., 2013), with high parasite specificity, which cause diseases and death. Ectoparasites are associated with stress conditions due to high density stocking 
(EL-SAYED, 2006) and decrease in water quality (VARGAS et al., 2000).

Due to the relevance of net-tank breeding and tilapias parasite diseases, current analysis identifies the prevalence of ectoparasites and bacteria diagnosis in the Nile tilapia, GIFT strain, bred in net-tanks with different densities, in the Corvo's river, State of Paraná, Brazil.

\section{Material and Methods}

\section{Study area}

The experiment was performed in net-tanks the experimental station located in the in the Corvo's river, an affluent of the Paranapanema river, tributary of the Rosana Hydro-electrical Plant reservoir which borders the municipalities of Diamante do Norte and Terra Rica in the State of Paraná, Brazil (Figure 1). Coordenad: $22^{\circ} 39^{\prime} 25.0 ” \mathrm{~S} ; 52^{\circ} 46^{\prime} 52.3$ ”W .

Figure 1. Location of the experimental station where the net-tanks were allocated to the experiment. Corvo's river, State of Paraná, Brazil. Coordenad: 22॰39’25.0”S; 5246’52.3”W|.

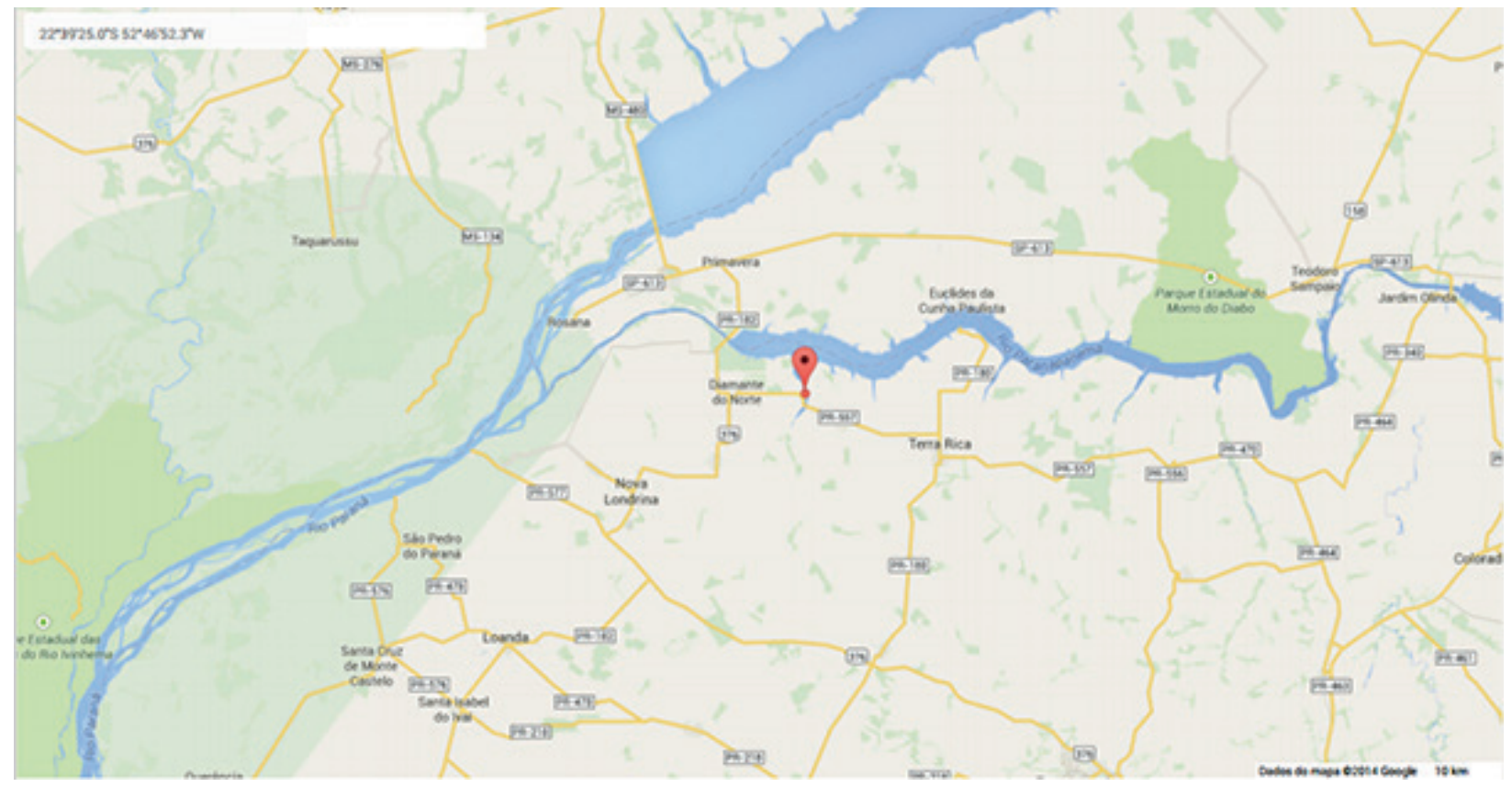

Source: Google Maps (2014).

\section{Experiment}

Experiment was undertaken in two cycles: Cycle A was installed in August 2010 with 155 days and Cycle B installed in February 2011 with 128 days. Twenty $6.8 \mathrm{~m}^{-3}(2.0 \times 2.0 \times 1.7 \mathrm{~m})$ net-tanks were employed with true capacity of $6.0 \mathrm{~m}^{-3}$, and five densities (150, 175, 200, 225 and $\left.250 \mathrm{fish} / \mathrm{m}^{-3}\right)$, with four replications for each density, with a total of 24.000 post-reversed juvenile Nile tilapia, GIFT strain.
The first identification on ectoparasite prevalence occurred at the establishment of the experiment (the start of each cycle). To this end, hundred specimens were anesthetized with benzocaine (dosage: $1 \mathrm{~g} / 10 \mathrm{~mL}$ alcohol $96^{\circ} \mathrm{GL}$ in $10 \mathrm{~L}$ water), was then gauged weight, total length and prevalence of ectoparasites.

During the experiment five samples were taken at intervals of thirty days, each sample consisted of five fish each replicate. In addition, monthly 
biometrics were undertaken to calculate fish biomass and adjust extruded commercial ration (32\% crude protein and $8 \mathrm{~mm}$ granulometry).

\section{Parasitological analysis}

Ectoparasites were determined by the examination of scrap from the first gill arc and dorsal region of the left side of each fish. Weight and total length of all samples were measured by 3-digit electronic balance and ichthyometer. Methodology was approved by the Committee for Ethics in the use of Animals in Experiments of the State University of Maringá, Maringá, State of Paraná, Brazil (Protocol 037/2010).

Prevalence rate was calculated, following Bush et al. (1997). Mean intensity for Monogenoidea was evaluated following Bush et al. (1997). In the case of tricodinids, mean infestation category was evaluated (category $1=1$ to 5 tricodinids; $2=6$ to 10 tricodininids; $3=11$ to 15 tricodinids; $4=16$ to 20 tricodinids; $5=$ over 20 tricodinids).

\section{Bacteriological analysis}

Two collections were performed in Cycle A for the bacteriological diagnosis: one was performed at implantation when 20 fish were collected; the other at the end of the cycle with a sample of 40 fish, with 8 fish per treatment. In Cycle B, three collections were undertaken with 20 fish during implantation, 40 in the intermediate phase and 40 at the end of the experiment, with eight animals per treatment.

After capture, the fish were placed in $80 \mathrm{~L}$ plastic caskets with water and oxygen under pressure. They were transported to the Laboratory of Veterinary Microbiology and Infectious Diseases of the
Department of Preventive Veterinary Medicine of the State University of Londrina where necropsy, bacteriological analyses of the liver and kidneys were undertaken and macroscopic alterations reported.

The samples of kidney and liver of each fish were aseptically harvested and plated on Columbia Agar with 5\% sheep blood plates were incubated at $30^{\circ} \mathrm{C}$ under aerobic conditions for five days.

\section{Water quality analysis}

Water's physical and chemical parameters, such as temperature, $\mathrm{pH}$, electric conductivity and dissolved oxygen, were performed. Variables related to water quality were analyzed once a month and registered by nichthemeral factors (samples taken in 24-hour periods at 6-hour intervals between one sample and another) and calculated the average.

\section{Statistical analyses}

Multiple regressions were adjusted for statistical analyses taking into consideration linear and quadratic relationships and interactions between effects and analyzed variables. Analyses were performed with PROC GLM of SAS.

\section{Results and Discussion}

Figures 2 and 3 show mean rates of the physical and chemical parameters of water monitored in the Corvo's river, State of Paraná, Brazil, respectively for Cycle A and Cycle B. Rates for $\mathrm{pH}$, electric conductivity and dissolved oxygen were according to conditions adequate for tropical fish culture, such as the Nile tilapia, following Martins et al. (2002). 
Figure 2. Physical parameters of water (Nichthemeral) in the Cycle A (between August 2010 and January 2011) evaluated in the Corvo's River, State of Paraná, Brazil. Legend: axis X: days after installation, $\rightarrow$ 06:00 hours,,10:00 hours, $\rightarrow$ 14:00 hours, $\nsucc$ 18:00 hours and $\leftarrow$ 24:00 hours.

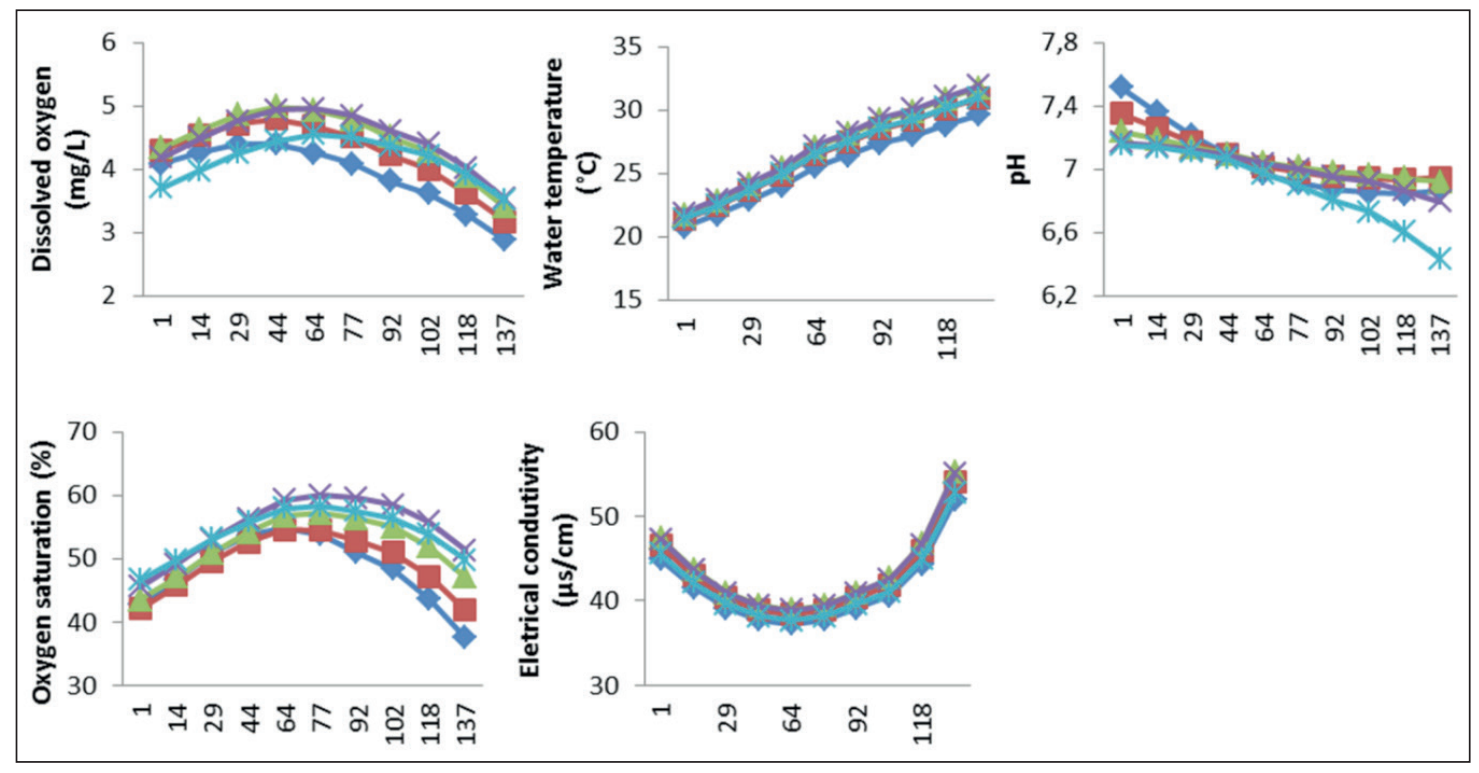

Figure 3. Evaluation of physical parameters of water (Nichthemeral) of Cycle B (between February 2011 and June 2011) evaluated in the Corvo's River, State of Paraná, Brazil. Legend: axis X: days after installation; verifications $\rightarrow-$ 06:00 hours, $-10: 00$ hours, $\rightarrow 14: 00$ hour, $\div$ 18:00 hours and $\div-24: 00$ hours.

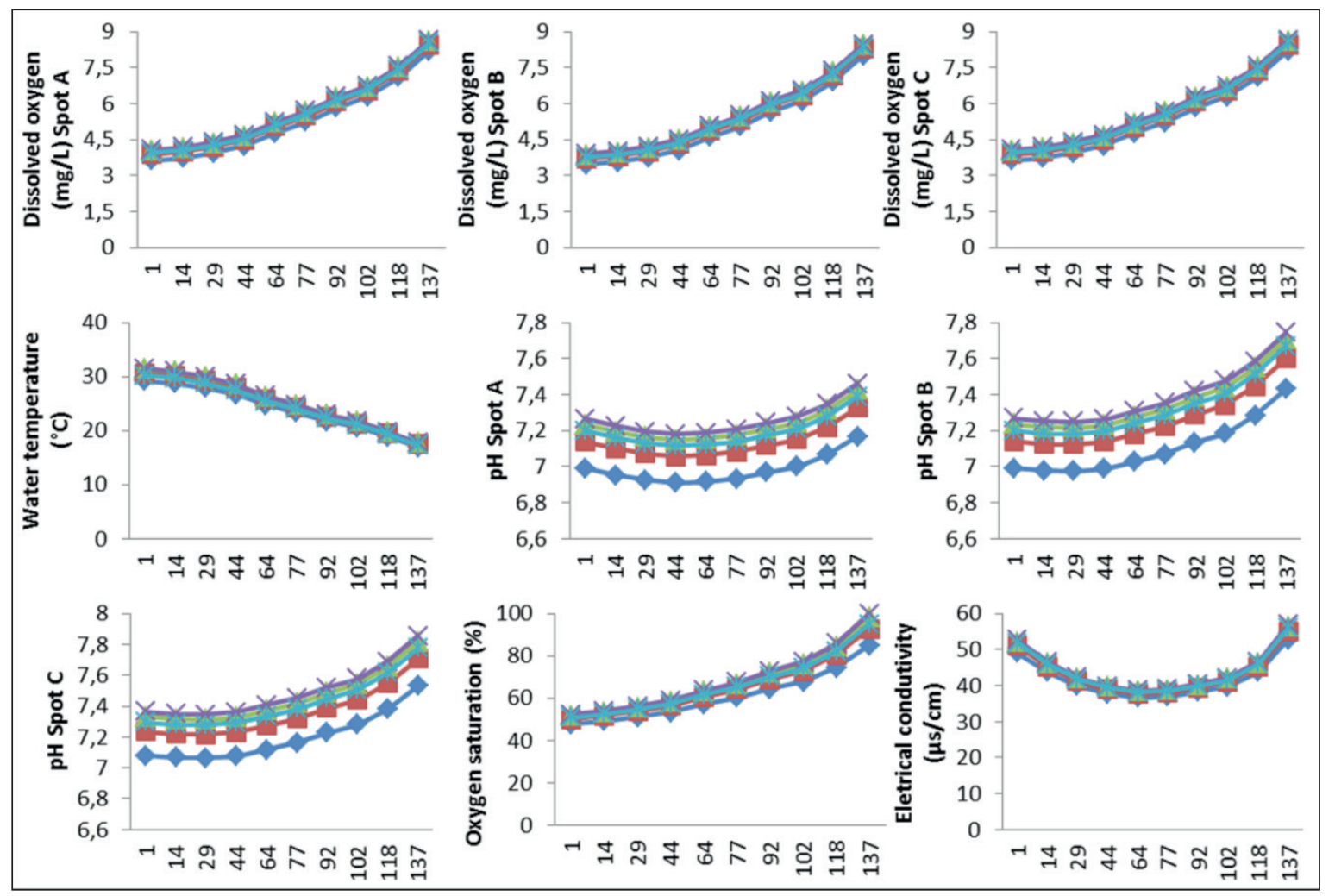


At the installation of the experiment Cycle A fish started with $94.0 \%$ total ectoparasite prevalence, featuring $37.0 \%$ tricodinids, $4.0 \%$ Monogenoidea and $53.0 \%$ mixed parasites. In Cycle B, the fish started with a total ectoparasite prevalence of of $98.0 \%$, featuring $49.0 \%$ tricodinids and $49.0 \%$ mixed parasites. Braccini et al. (2007) reported similar results, with high prevalence of ectoparasites in the implementation of the experiment (arrival of fingerlings in Cycle A), but the same authors reported a predominance of tricodinids.

Net-tank system fish in a natural environment are related interdependently with the habitat and other agents such as pathogens (ARANA, 2004). Apparently, tricodinid protozoa live as ectocommensals the integument and gills of the fish without causing major damage, except in heavy infestations (ZANOLO; YAMAMURA, 2006). In their research on Nile tilapia fries, Vargas et al. (2000) diagnosed in the municipality of Maringá, State of Paraná, Brazil, high occurrence of the protozoon Trichodina, in different experimental conditions, and underscored that the parasite was highlighted by its great numbers and might eventually cause liabilities especially in fish health.

Maintenance, reproduction and high infestations by Monogenoidea and tricodinids are related to the eutrophized environment with low oxygen rates, lack of renewal, organic pollution in tanks with high breeding densities (ARANA, 2004; MARTINS at al., 2002), fixation and adaptation of the parasite to the host, and stress situations in which diseases occur (GOMES et al., 2003; EL-SAYED, 2006; PORTZ, 2006; ZANOLO; YAMAMURA, 2006). The above coincide with age of fish in the experiment (juvenile phase) in which they probably did not have any response to the mechanism immune to a decrease in ectoparasite population (BUCHMANN, 1999).

No significant difference was reported in the prevalence of ectoparasites with regard to the five densities under analysis (150, 175, 200, 225 and $250 \mathrm{fish} / \mathrm{m}^{3}$ ). Results are very close to those by Martins et al. (2006) who reported that there was no relationship with the number of parasites in fish bred at high density levels. Rojas (2006) underscored the importance of management care in water quality with regard to pathologies of aquatic organisms. Further, Braccini et al. (2007) reported that increase in parasite load was not related to high stocking densities.

Cycle A showed an increase in Trichodina prevalence and a decrease in the prevalence of Monogenoidea and mixed parasites (September to November 2010). On the other hand, an inverse relationship, a decrease in the prevalence of Trichodina and an increase in the prevalence of Monogenoidea and mixed parasites occurred during December and January (Figure 4). Buchmann (1999) uggested that an increase in Trichodina during the juvenile phase was caused by a lack of adequate response to the mechanism immune to ectoparasite population decrease. Although water quality was adequate, dissolved oxygen decreased during the period. The above condition may explain the small increase in infestation by Monogenoida (Figure 2). Macphee (2001) reported that the main motivating factors for infestation by Monogenoidea are overstocking and water degradation in the system.

Significant prevalence of ectoparasites in Cycle B occurred, with a decrease between March and April, followed by an increase in May and June (Figure 5). Studies on parasites by Martins et al. (2006), Vargas et al. (2003) and Ranzani-Paiva et al. (2005) related the Nile tilapia's health conditions to parasite prevalence in different regions and at different times of the year. They reported Trichodina, associated with other parasites, in the branchias and skin during the warmest month. Research by Vargas et al. (2000), Ranzani-Paiva et al. (2005) and Martins et al. (2006) revealed high prevalence of Trichodina sp. in the ectoparasites of the Nile tilapia. Protozoon in tilapias indicates low water quality due to excess of organic matter, associated with low temperature which raises parasite infection rates in fish (RANZANI-PAIVA et al., 2005). 
Figure 4. Prevalence of ectoparasites (Tricodinids, Monogenoidea and mixed parasites) of Cycle A (between August 2010 and January 2011) evaluated in the Corvo's River, State of Paraná, Brazil.

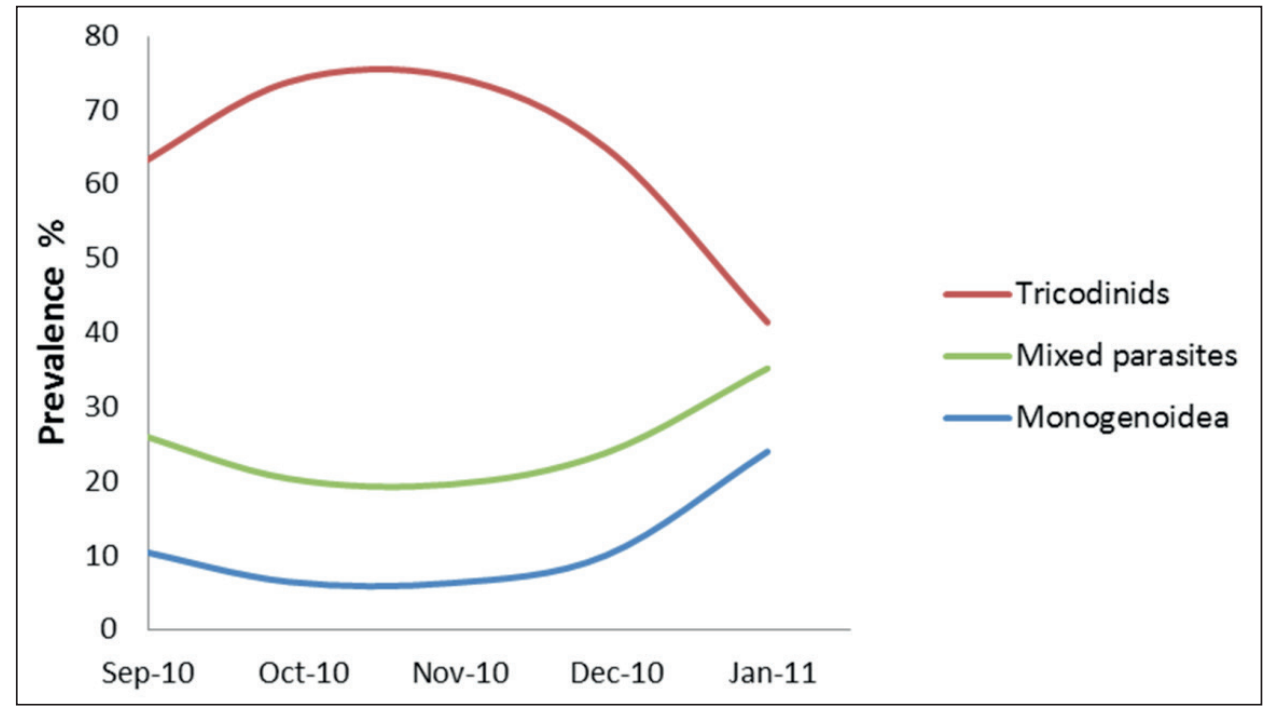

Figure 5. Prevalence of ectoparasites (Tricodinids, Monogenoidea and mixed parasites) in Cycle B (between February 2011 and June 2011) evaluated in the Corvo's River, State of Paraná, Brazil.

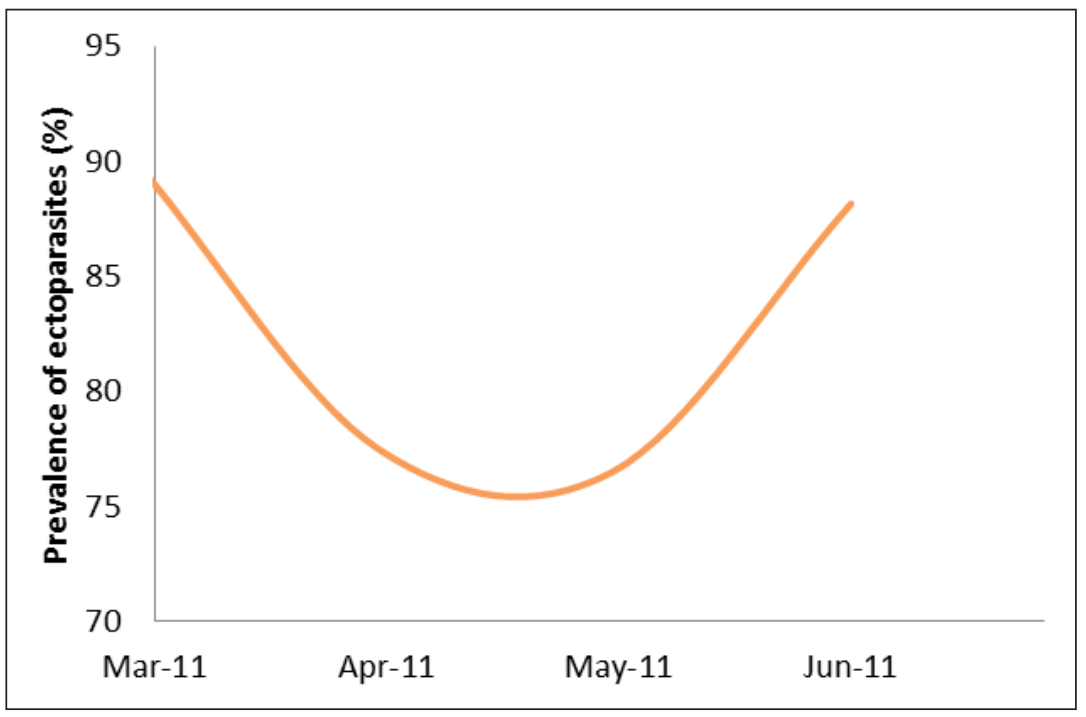

No significant differences between densities occurred in the category mean infestation by tricodinids and average intensity of Monogenoidea in Cycle A. However, Cycle B showed a significant difference for the category mean infestation by tricodinids in which there was an increase of parasites in high densities (Figure 6). The months of May and June Cycle B are the driest and coldest during the experiment. Low temperature can reduce appetite and suppress the immune system, predisposing the fish to attack by pathogens (KUBITZA; KUBITZA, 2004). Zago et al. (2014), observed that abundance of Trichodina spp. were higher in the dry season. Therefore, greater care with stocking density and management of the animals are very important in this period. 
Figure 6. Category of infestation by tricodinids in Cycle B (from March to June 2011) evaluated in the Corvo's River, State of Paraná, Brazil.

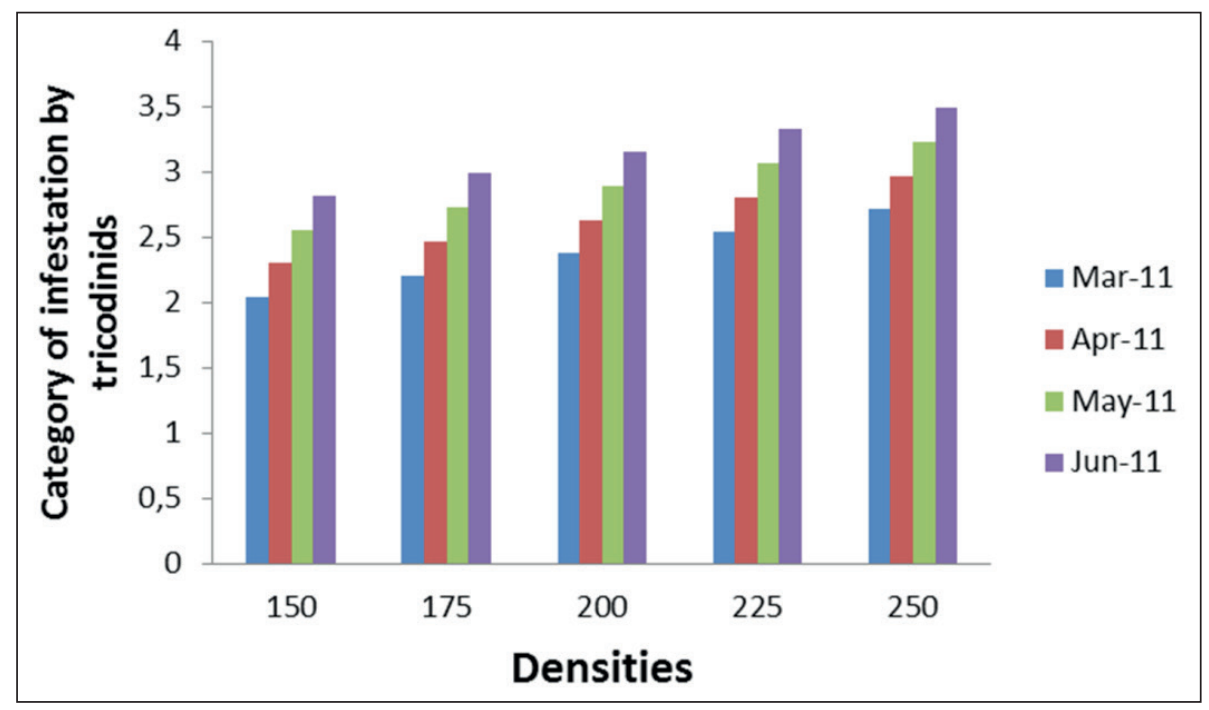

Bacteriological results of the two experimental periods revealed negative results. The pathogenic bacteria such as Streptococcus spp. is associated with stress conditions related to water quality and intense breeding conditions (BUSH et al., 1997), results show that good management practice had been employed coupled to favorable conditions of water and cleanliness of net-tanks during the installation and development of the experiments.

\section{Conclusion}

There was no significant difference in the prevalence of ectoparasites with regard to densities in the two cycles of the experiment. A significant difference occurred in the total ectoparasite prevalence with regard to the month of Cycle B. In other words, between March and June the category infestation by tricodinids increased according to increase in density throughout the experiment. More caution with high densities during the period is thus required.

Bacteriological analysis provided negative results for both cycles and indicated that good management practices were efficient for the control of bacteriosis.

\section{Acknowledgments}

The authors are grateful to CNPq and "Projeto Aquabrasil"- EMBRAPA for financial support. We thank members of the PeixeGen Group at the State University of Maringá for help in developing the Work.

\section{References}

AKOLL, P.; KONECNY, R.; MWANJA, W. W.; NATTABI, J. K.; AGOE, C.; SCHIEMER, S. Parasite fauna of farmed Nile tilapia (Oreochromis niloticus) and African catfish (Clarias gariepinus). Parasitology Research, Uganda, v. 110, n. 1, p. 315-323, 2012.

ARANA, L. V. Fundamentos de aquicultura. Florianópolis: USFC, 2004. 348 p.

BONDAD-REANTASO, M. G.; SUBASINGHE, R. P.; ARTHYR, J. R.; OGAWA, K.; CHINABUT, S.; ADLARD, R.; TAN, Z.; SHARIFF, M. Disease and health management in Asian aquaculture. Veterinary Parasitology, Amsterdam, v. 132, n. 3-4, p. 249-272, 2005.

BRACCINI, G. L.; NATALI, M. R. M.; RIBEIRO, R. P.; MORI, R. H.; RIGGO, R.; OVIREIRA, C. A. L.; HILDEBRANDT, J. F.; VARGAS, L. Morpho-functional response of Nile tilapia (Oreochromis niloticus) to a homeopathic complex. Homeopathy, Luton, v. 102, n. 4, p. 233-241, 2013. 
BRACCINI, G. L.; VARGAS, L.; RIBEIRO, R. P.; TAKEMOTO, R. M.; LIZAMA, M. A. P.; FÜLBER, V. M. Ectoparasitos de tilápia do Nilo (Oreochromis niloticus), das linhagens Chitralada e GIFT, em diferentes densidades e alimentadas com dois níveis de proteína. Acta Scientiarum: Animal Sciences, Maringá, v. 29, n. 4, p. 441-448, 2007.

BUCHMANN, K. Immune mechanisms in fish skin against monogeneans - a model. Folia Parasitology, Ceske Budejovice, v. 46, n. 1, p. 1-9, 1999.

BUSH, A. O.; LAFFERTY, K. D.; LOTZ, J. M.; SHOSTAK, A. W. Parasitology meets ecology on its own terms: Margolis et al. revisited. Journal of Parasitology, Lawrence, v. 83, n. 4, p. 575-583, 1997.

EL-SAYED, A. F. M. Stress and diseases. In: Tilapia culture. Wallingford, UK: CABI Publishing, 2006. chap. 8, p. 139-159.

GOMES, L. C.;ARAUJO-LIMA, C.A. R. M.; ROUBACH, R.; CHIPPARI-GOMES, A. R.; LOPES, N. P.; URBINATI, E. C. Effect of fish density during transportation on stress and mortality of juvenile tambaqui, Colossoma macropomum. Journal of the World Aquaculture. Society, Baton Rouge, v. 34, n. 1, p. 76-84, 2003.

GOOGLE MAPS. Location of the experimental station where the net-tanks were allocated to the experiment. Corvo's river, State of Paraná, Brazil. Coordenad: 22॰39'25.0”'S; 5246’52.3”W. [S.1.: s.n.], 2014. Available at: $<$ https://www.google.com.br/maps/place $/ 22 \% \mathrm{C} 2 \% \mathrm{~B} 03$ 9'25.0\%22S+52\%C2\%B046'52.3\%22W/@,22.7747544,$52.6878106,10 \mathrm{z} /$ data $=! 4 \mathrm{~m} 2 ! 3 \mathrm{~m} 1 ! 1 \mathrm{~s} 0 \times 0: 0 \mathrm{x} 0>$. Accessed at: 10 nov. 2014.

KUBITZA, F.; KUBITZA, L. M. M. Principais parasitoses $\mathrm{e}$ doenças dos peixes cultivados. In: KUBITZA, F. Coleção de piscicultura avançada. 4. ed. Jundiaí: F. Kubitza, 2004. p. 4-116.

LIMA, L. C.; LEITE, R. C. Boas coletas garantem bons diagnósticos. Panorama da Aquicultura, Rio de Janeiro, v.16, n. 96, p. 24-29, 2006.

MARTINS, M. L.; GHIRALDELLI, L.; AZEVEDO, T. M. P. Ectoparasitos de tilápias (Oreochromis niloticus) cultivadas no Estado de Santa Catarina, Brasil. In: SOUZA-SILVA, A. T. (Org.). Sanidade de organismos aquáticos no Brasil. Maringá: ABRAPOA, 2006. cap. 13., p. 253-270.

MARTINS, M. L.; ONAKA, E. M.; MORAES, F. R.; BOZZO, F. R.; PAIVA, A. M. F. C.; GONÇALVES, A. Recent studies on parasitic infections of freshwater cultivated fish in the State of São Paulo, Brazil. Acta Scientiarum Animal Science, Maringá, v. 24, n. 4, p. 981985, 2002.
MACPHEE, D. Monogenean (fluke) infestations of the gills of farmed salmon in Maine and New Brunswick. In: ANNUAL NEW ENGLAND FARMED FISH HEALTH MANAGEMENT WORKSHOP, 9., 2001, New England. Proceeding... New England: New England Farmed fish health management, 2001. p. 134-140.

MENEZES, L. C. B.; BEYRUTH, Z. Impactos da aquicultura em tanques-rede sobre a comunidade bentônica da represa de Guarapiranga - São Paulo - SP. Boletim do Instituto de Pesca, São Paulo, v. 29, n. 1, p. 77-86, 2003.

PORTZ, L. Recentes avanços na imuno-nutrição de peixes. In: SILVA-SOUZA, A. T. (Org.). Sanidade de organismos aquáticos no Brasil. Maringá: Abrapoa, 2006. pt. IV, cap. 11, p. 229-238.

RANZANI-PAIVA, M. J. T.; FELIZARDO, N. N.; LUQUE, J. L. Parasitological and hematological analysis of Nile tilapia Oreochromis Niloticus Linnaeus, 1757 from Guarapiranga reservoir, São Paulo State, Brazil. Acta Scientiarum Biological Sciences, Maringá, v. 27, n. 3, p. 231-237, 2005.

ROJAS, N. E. T. Manejo da qualidade da água em viveiros de piscicultura continental. In: SILVA-SOUZA, A. T. Sanidade de organismos aquáticos no Brasil. Maringá: ABRAPOA, 2006. pt. I, cap. 3, p. 63-76.

VALLADÃO, G. M. R.; PÁDUA, S. B.; GALLANI, S. U.; MENEZES-FILHO, R. N.; DIAS-NETO, J.; MARTINS, M. L.; PILARSKI, F. Paratrichodina africana (Ciliophora): a pathogenic gill parasite in farmed Nile tilapia. Veterinary Parasitology, Amsterdam, v. 13, n. 3-4, p. 705-710, 2013.

VARGAS, L.; POVH, J. A.; RIBEIRO, R. P.; MOREIRA, H. L. M. Ocorrência de ectoparasitos em tilápias do Nilo (Oreochromis niloticus), de origem tailandesa, em Maringá-Paraná. Arquivos de Ciências Veterinárias e Zoológicas da Unipar, Umuarama, v. 3, n. 1, p. 31-37, 2000.

VARGAS, L.; POVH, J. A.; RIBEIRO, R. P.; MOREIRA, H. L. M.; LOURES, B. T. R. R.; MARONEZE, M. S. Efeito do Tratamento com cloreto de sódio e formalina na ocorrência de ectoparasitas em alevinos de Tilápia do Nilo (Oreochromis niloticus) revertidos sexualmente. Arquivos de Ciências Veterinárias e Zoologia da Unipar, Umuarama, v. 6, n. 1, p. 61-66, 2003.

ZAGO, A. C.; FRANCESCHINI, L.; GARCIA, F.; SCHALCH, S. H. C.; GOZI, S. G.; SILVA, R. J. Ectoparasites of Nile tilapia (Oreochromis niloticus) in cage farming in a hydroelectric reservoir in Brazil. Brazilian Journal Veterinary Parasitology, Jaboticabal, v. 23, n. 2, p. 171-178, 2014. 
ZANOLO, R.; YAMAMURA, M. H. Parasitas em tilápias-do-nilo criadas em sistema de tanques-rede. Semina: Ciências Agrárias, Londrina, v. 27, n. 2, p. 281288, 2006. 